International Journal of Environment, Agriculture and Biotechnology
Vol-6, Issue-4; Jul-Aug, 2021
J Journal Home Page Available: https://ijeab.com/
Journal DOI: $10.22161 /$ ijeab

\title{
Introduction of Feed Technology in Support Development of Beef Cattle
}

\author{
Femi Hadidjah Elly, Artise H.S. Salendu, Agustinus Lomboan, Zulkifli Poli, Anneke K. \\ Rintjap
}

Faculty of Animal Husbandry University of Sam Ratulangi, Manado, North Sulawesi, Indonesia

Correspondence Email: artisesalendu@yahoo.com

Received: 05 Jul 2021; Received in revised form: 12 Aug 2021; Accepted: 20 Aug 2021; Available online: 31 Aug 2021

(C2021 The Author(s). Published by Infogain Publication. This is an open access article under the CC BY license

(https://creativecommons.org/licenses/by/4.0/).

\begin{abstract}
The problem of beef cattle breeding developed by rural communities was done traditionally. Farmers use land under coconut for raising beef cattle, but feed consumed was low quality grass. This condition has an impact on low productivity of beef cattle so that selling price was also low. This research was conducted with the aim of analyzing potential for forage development in Bolaang Mongondow Regency. The research method used was a survey, with determination of location is by purposive sampling, which was village that has most cattle population. Data collected were primary and secondary. Respondents were determined by purposive sampling, namely 30 farmers who use land under a coconut tree. Data were analyzed descriptively and using IDD analysis. PMSL Value 21396.39, KPPTR(SL) 12043.76, PMKK Value 107557.8, KPPTR (KK) 87438.8. The carrying capacity index value of 1.40 shows that based on potential of existing land, real population can still be increased up to 1.40 times. In conclusion, development of land under a coconut can be done through introduction of forage. Suggestion, forage is developed by considering its quality.
\end{abstract}

Keywords-forage, beef cattle, coconut land, introduction.

\section{INTRODUCTION}

The agricultural sector is a sector that contributes significantly to the development of the local, regional and national economy. The paradigm of future agricultural development is sustainable agricultural development, industrial culture, global competitiveness, and has an ecosystem approach. The ecosystem in question is an ecological system formed by an inseparable reciprocal relationship between living things and their environment. An order of unity as a whole and as a whole between all elements of the environment that influence each other is also included in the ecosystem.

Bolaang Mongondow Regency develops the agricultural sector which includes food crops, plantations, livestock, fisheries and horticulture sub-sectors. The development of food crops is related to rice, corn and soybeans. The development of the three food crops is the realization of a government program whose goal is to be self-sufficient. But soybeans were less successful in this area so that there was very little interest from farmers in this area to develop it. Program to increase production, productivity and quality of food crops to achieve sustainable self-sufficiency in rice and maize. Land support and the availability of feed are urgently needed to encourage farmers to develop beef cattle farming businesses (Rusdiana and Talib, 2019).

The Bolaang Mongondow Regency Government continues to encourage an increase in the population of beef cattle so that this commodity becomes a priority in the development of the livestock sector. The problem is that beef cattle farming is developed traditionally. Whereas beef cattle farming has many roles and functions and is very meaningful for smallholder farmers' businesses in rural areas (Sodiq et al. 2017). Farmers use agricultural land, both dry land for food crops and land under coconut trees to graze beef cattle. Beef cattle in this case consume field grass that grows wild on these lands. On the other hand, some farmers develop beef cattle in cages but the feed given is rice straw or corn straw which is of low quality. This condition shows that the productivity of beef cattle is lower than the same cattle in other areas in North Sulawesi. The low productivity of cattle causes the selling price is also low. 
Based on the thoughts and problems above, a study was carried out on the need for the introduction of feed technology as a staple food for beef cattle. This research was conducted with the aim of knowing the potential for forage development for beef cattle in Bolaang Mongondow Regency.

\section{RESEARCH METHODS}

The research method used was a survey method, through direct interviews with farmers using a list of questions. The data collected were primary and secondary data. Primary data obtained from interviews and direct observation of farmers. The research location was determined by purposive sampling, namely by considering the village that had the largest cattle population. Respondents were determined by purposive sampling, namely 30 farmers who used land under coconut trees. Analysis of the data used was descriptive analysis and carrying capacity index.

\section{RESULTS AND DISCUSSION}

The cattle business in the study area was developed traditionally with a total ownership of about 2-6 heads (according to the results of the study). This amount is categorized as a household scale and was developed to cultivate agricultural land and was used to transport agricultural products. In fact, beef cattle business in rural areas is expected to support the national demand for beef. This is a great opportunity for farmers to develop beef cattle (Steflyando et al. 2014). The slow increase in cattle productivity was caused by various obstacles (Elly et al. 2018a, Elly et al. 2018b, Elly et al. 2019a, Elly et al. $2019 b)$. One of the obstacles faced by cattle farmers in the research location was the problem of feed. Factors that become obstacles in developing beef cattle include land as an ecological basis for raising beef cattle that has not been optimized (Sodiq et al. 2018).

The feed needed by beef cattle does not only play a role in meeting basic life needs but also for increasing production and quality of meat. Feed in this case should receive attention from both farmers and the government. Feed must be available continuously to cover the needs of cattle. However, the available feed must have quality to meet the nutritional needs of beef cattle. The provision of quality feed must also be followed at an affordable price. The cost of feed for beef cattle is the biggest cost (Rusdiana and Praharani, 2018). The increase in body weight of cattles is influenced by feed factors (Nur et al. 2018).

The results showed that the research location had the potential for development under coconut trees for forage development. The carrying capacity of land in Bolaang Mongondow Regency was seen from the potential for effective livestock development and carrying capacity index. The potential for effective livestock development was analyzed using the maximum potential based on land resources (PMSL), the capacity to increase the cattle population based on land resources (KPPTR (SL), the maximum potential based on the head of the farming family (PMKK) and the capacity to increase the cattle population based on the head of the family (KPPTR (KK), and land carrying capacity index (IDD).The conditions of maximum potential and IDD analysis are stated in Table 1.

The data in Table 1 shows that the maximum potential value in cattle units in Bolaang Mongondow based on land resources (PMSL) according to the results of the analysis was 21,396.39. This value indicates that based on land resources in the research area it can still accommodate a population of beef cattle of 21,396.39 AU.

Table 1. Maximum Potential Condi-tions and IDD Analysis in Bolaang Mongondow Regency

\begin{tabular}{llr}
\hline No & Coefficient/Variable & \multicolumn{1}{c}{ Value } \\
\hline 1. & PMSL & $21.396,39$ \\
2. & KPPTR(SL) & $12.043,76$ \\
3. & PMKK & $107.557,80$ \\
4. & KPPTR(KK) & $87.438,80$ \\
5. & IDD & 1,40
\end{tabular}

Descriptions :

PMSL = Maximum potential in cattle unit (AU) based on land resources

$\operatorname{KPPTR}(\mathrm{SL})=$ Capacity to increase cattle population $(\mathrm{AU})$ based on land resources

PMKK = Maximum potential (AU) based on farmer's family head

$\operatorname{KPPTR}(\mathrm{KK})=$ Capacity to increase cattle population $(\mathrm{AU})$ by Head of Family

IDD = Carrying Capacity Index

Furthermore, the value of the capacity for increasing the population of cattle based on land resources (KPPTR(SL) according to the results of the analysis was $12,043.76$ (Table 1). This value indicates that to meet the maximum potential of land resources, the population of cattle in the study area can still be increased to as much as $12,043.76$ AU.

The maximum potential value based on the head of the farmer's family (PMKK) according to the results of the analysis was $107,557.80$ (Table 1). These results indicate 
that based on the availability of labor, with each having 3 $\mathrm{AU}$, the cattle population can be increased to $107,557.80$ AU. The value of the capacity for increasing the population of cattle based on the head of the family (KPPTR (KK) according to the analysis was $87,438.80$ (Table 1). This value indicates that the increase in the number of farmers as the head of the family, the population of beef cattle can be increased by $87,438.80$ AU.

The carrying capacity index value in Table 1 was 1.40 which indicates that based on the existing land potential, the real population can still be increased up to 1.40 times. Based on this value, it shows that the cattle population in the study area can still be increased. The Carrying Capacity Index according to the results of research that has been carried out by several researchers was to show the status of the land in the provision of feed (Anggraini and Putra. 2017)

Based on the potential of the land above, it is necessary to introduce quality forage technology such as dwarf grass. Forage was all feed sources of crude fiber derived from plants, especially green plant parts (Salendu and Elly, 2012).

The introduction of technology is an innovation for the progress of the beef cattle business depending on the characteristics of the cattle farmers. The characteristics of farmers based on various studies not only affect the success of their businesses but also affect technology adoption (Mauludin, 2012) and (Suteky et al. 2017). Characteristics of farmers that affect the introduction of feed technology include age and education level. The age of respondents ranged from 32 to 66 years, with the highest distribution being respondents ranging from 32 to 64 years ( 86.67 percent). Farmers who were over 65 years old were only around 13.13 percent. The age of the respondents was categorized as productive age. This condition shows that farmers had physical ability in managing beef cattle business. Age can also had an impact on farmers in making decisions to apply the introduced technology. Behavior in making decisions, and being able to work optimally and productively was influenced by the age of the farmer (Tarmizi et al. 2018).

Education is also one of the factors that influence farmers in applying the introduced technology. The level of education of respondents according to the results of the study was mostly categorized as low. The largest distribution of education was elementary school graduates (53.33 percent) followed by those who did not graduate from elementary school and junior high school graduates (each 16.67 percent). The remaining 13.33 percent finished high school. This condition has an impact on the slowness of farmers in accepting or adopting technology. The level of education affects the adoption of innovation and technology by farmers in raising livestock (Mulyawati et al. 2016). The indication is that this situation will affect the way of thinking, learning ability, and intellectual level of farmers. The role of extension workers in this case is very important. The government needs to intervene and assist farmers in introducing feed technology.

\section{CONCLUSIONS AND SUGGESTIONS}

Based on the results of the study, it can be concluded that the development of land under coconut trees can be done through the introduction of forage. Suggestions, forage that can be developed should be quality forage.

\section{ACKNOWLEDGEMENT}

Thank you to the Rector, Chair and Secretary of the LPPM and the Dean of the Faculty of Animal Husbandry UNSRAT, who gave the author the opportunity to obtain research funding through SKIM RTUU.

\section{REFERENCES}

[1] Anggraini, Nand R.A. Putra. 2017. Regional Potential Analysis in Beef Cattle Farming Development in Sijunjung District, Sijunjung Regency. Journal of Agrifo, 2 (2) : 82100.

[2] Elly, F.H., A.H. Salendu., Ch. L. Kaunang., Indriana., Syarifuddin and R. Pomolango. 2018 (a). Empowerment of Farmers in Efforts to Develop Sustainable Cattle Farming in Sangkub District Regency of North BolaangMongondow, North Sulawesi Province, Indonesia. Proceeding The Fourth International Seminar on Animal Industry. IPB International Convention Centre, Bogor Indonesia, August, 28-30 2018.

[3] Elly, F.H., A.H.S. Salendu, Ch. L. Kaunang, Indriana, R. Pomolango, and Syarifuddin. 2018 (b). Forage Introduction to Support Development of Cattle in Sangkub District. International Journal of Environment, Agriculture and Biotechnology (IJEAB), 3 (5) : 1718-1720.

[4] Elly, F.H., A. Lomboan, C. L. Kaunang and R. Pomolango. 2019 (a). Benefits of Integrated Farming System for Cattle Crops in North BolaangMongondow Regency North Sulawesi Province, Indonesia. International Journal of Agriculture, Environment and Bioresearch (IJAEB),4 (4) : $1-5$.

[5] Elly, F.H., A. Lomboan., Ch. L. Kaunang., M. Rundengan and Syarifuddin. 2019 (b). Development Potential of Integrated Farming System (Local Cattle-Food Crops). J. Animal Production. 21 (3): 143-147.

[6] Mauludin, M.A., S. Winaryantoand S. Alim. 2012. The Role of Groups in Developing the Empowerment of Beef Cattle Breeders (Case in the Southern Region of 
Tasikmalaya Regency). Journal of Animal Science, 12 (1) : $1-8$

[7] Mulyawati, I.M., D. Mardiningsih, and S. Satmoko. 2016. Effect of Age, Education, Experience and Number of Goat Farmers on the Behavior of Sapta Goat Farming Business in Wonosari Village, Patebon District. Journal of Agromedia, 34 (1) : 85-90.

[8] Nur, T.M., C. Fadli, and H. Satriawan. 2018. Analysis of Potential Integration of Oil Palm Cattle in Bireuen Regency, Aceh Province. Journal of Agribusiness and Rural Development Research, 4 (2) : 69-80.

[9] Rusdiana, S and C. Talib. 2019. Government Policy Supports Increase in Beef Cattle Business in Breeders. Journal of Agricultural Socio-Economic Agribusiness (SOCA), 13 (3) : 380-395.

[10] Rusdiana, Sand L. Praharani, 2018. Beef Cattle Farming Development: Beef Self-Sufficiency Policy and Feasibility of Livestock Business. Agro-Economic Research Forum, 36 (2) : 97-116.

[11] Salendu, A.H.Sand F.H. Elly. 2012. Utilization of land under coconut trees for forage for cattle in North Sulawesi. Pastura Journal, 2 (1) : 21-25.

[12] Sodiq, A.,Suwarno, F. R. Fauziyah, Y. N. Wakhidatiand P. Yuwono. 2017. Beef Cattle Farming Production System in Rural and Its Development Strategy. Journal of Agrippet, 17 (1) : 60-66.

[13] Sodiq, A., P. Yuwono, Y. N. Wakhidati, A. H. Sidhi, M. Rayhanand A. Maulianto. 2018. Beef Cattle Farming Development through Cluster Program: Description of Programs and Activities. Journal of Agrippet, 18 (2) : 103109.

[14] Steflyando, R., Abubakar and A. Saleh. 2014. Feasibility Analysis of Beef Cattle Business with Zero Waste Farming Method in Parongpong District. Journal of Reka Integra, 1 (4) : 226-237.

[15] Suteky, T., Sutriyono., Dwatmadjiand M. I. Sholihin. 2017. Quality of Semen Production of UPTD Bengkulu and Success Rate of Insemination in Bali Cattle and Simmental Crossbreeds in Bengkulu. Indonesian Journal of Animal Science, 12 (2) : 221-229.

[16] Tarmizi, N.B.Dasruland G. Riady. 2018. The success of artificial insemination (IB) in Aceh cattle using frozen semen of Bali, Simental, and Limousine cattle in Mesjid Raya District, Aceh Besar Regency. JIMVET, 2(3) : 318328. 